\title{
The Platform Design and Implementation of Modern Education Teaching Based on the Mobile Network
}

\author{
Ying Wang \\ Wuhan City Polytechnic, Wuhan, Hubei Province, China
}

Keywords: Mobile network, the modern education, education teaching, platform design and implementation.

\begin{abstract}
This paper introduces the advantages of modern education technology and the present situation of the application of information research and development status of cloud computing on the influence of the teaching resources of colleges and universities; research the mobile teaching system is implemented. Sums up the problems existing in the traditional teaching mode, the teaching system based on mobile network to carry out the demand analysis, analysis of the need to build the teaching system of functional requirements, feasibility and risk analysis, finally, the construction of teaching system and implementation in detail, in order to the personalized education for colleges and universities to develop a new road.
\end{abstract}

\section{Introduction}

With the development of mobile communication technology and Internet technology, mobile Internet has become a current trend. Mobile Internet sex anytime and anywhere, greatly satisfy the requirements of information to the people in the mobile. With WAP technology matures, the WAP technology shows a mobile communication terminal standard way to connect to the Internet, mobile devices can be easily access to the Internet information. Due to the huge information resources of the Internet and mobile terminals, can rapidly make the mobile office and e-commerce system based on WAP technology is rapidly into people's work life in [1].

The national most colleges and universities have been built in educational administration information management platform based on WEB, and mobile phone also has a universal in scope of teachers and students. Therefore, with the aid of existing WEB campus network resources, combined with mobile communication technology for the teachers and students to provide personalized mobile teaching information service is becoming a hot spot of research and application of the next generation network [1]. Design and develop a set of office management system is a complex and huge system engineering. Office management system in order to adapt to the trend of the development of higher education reform, and the need of colleges and universities own development and foreign exchange, set up the educational administration management information system must satisfy certain requirements and conditions.

\section{The current status research of Mobile Internet and educational administration system at home and abroad}

For school administration management system, the function of the main realization teachers and student achievement are contained in the query results of entry. Query and student achievement method is mainly through the traditional letter notice, telephone inquiry, online query and query text messaging on mobile phones and so on several stages. Also, the teacher achievements recorded through the paper, the online school and so on several stages [2].

At present, although the popularity of the Internet has reached the unprecedented, but it is limited by the cable entry. And at present due to the popularity of mobile communications equipment makes the wireless communication network covers almost every corner of the country. Therefore, as long as the one which has the function of WAP mobile phone cannot be restricted by time, area and equipment, easy entry or obtain information [2]. Developed using WAP mobile phone can enter or 
query result of the system will be an important complement to Internet performance management, has great practical significance. With the continuous development of the Internet and mobile communication technology, our way of communication has had the fundamental change, Internet and mobile phones become more and more common communication tools. It is expected that by 2013, the number of mobile Internet users around the world will be more than the number of users to use computers, 1.78 billion [2]. The development of WAP technology and mature wireless business for people to get all sorts of information provided in addition to the Internet a more convenient way. Compared with traditional network management system, the son of office management system based on mobile Internet platform has the advantage of below:

\subsection{Interactive.}

To strengthen the management office of the contact with the school of communication between teachers and students, that will improve the efficiency of educational administration.

\subsection{Accuracy.}

Instant information to ensure the data accurate, don't miss the academic information update at any time.

\subsection{Immediacy.}

Students and teachers can query, update the educational administration information anytime and anywhere, in the operation of related services.

\section{The design idea of teachers' education network teaching platform}

According to the requirement of the life-long education thought to teacher education and teacher education informationization, the development of teacher education as the backing, a new runtime environment designed for teacher education, teacher education network teaching platform [3]. Design goal: implementation of the platform network curriculum made more functional; Lifelong teacher network learning; Systematic realization of teachers' personal knowledge management; Implement the school quality of network learning resources.

According to the demand of the education teaching platform has the following four functions:

1) to provide free normal students as the main body of the distance education master's network learning resources and services, so that it will be a master of the remote education the main way to complete their studies;

2) To provide the school undergraduate learning resources and services, to become "the second classroom";

3) as the main position of distance teacher training, training for primary and secondary school teachers in the Midwest and even the national development corresponding courses;

4) For the whole society within the scope of the resources to provide free and open learning. Teachers' education network teaching platform design includes the following several aspects.

\subsection{The integration of network teaching.}

Teacher education network teaching platform should not be only a single resource combination, and should combine resources and teaching, to support teacher education pre-service, after various teaching activities, including: learning resources, learning evaluation, monitoring, learning tools and support services [3]. Learners can online learning not only the teacher education curriculum content in network teaching platform, can also participate in the corresponding online learning activities, and teachers to interact, online assignments and tests.

\subsection{The mass production of network course.}

Network course construction need to experience the demand analysis, structure design, learning environment design, open classes, test, and only for a curriculum design, the development cycle is long, low efficiency. Teacher education platform in the design process, fully consider the traditional 
network curriculum design and development, in the process of platform design, the network curriculum template is constructed [4]. The template is in the thorough analysis and summary network curriculum characteristics and structure on the basis of design. The column includes: introduction, teachers, course features, study guide, teaching plan, teaching methods and evaluation, etc. Interface design with two or three columns of the structure. Teachers can also be more courses in the platform construction, in which students can select courses you need to online learning, realize the rapid generation of network course and batch production.

\subsection{Network teaching personality.}

Teacher education platform in the consideration of network course production cycle at the same time, also recognize that each course has its own characteristics, so in terms of network curriculum design, with some personalized Settings [4]. Teachers can according to the course itself need to add columns, content and tools, interface style, Settings, guarantee of the construction of the course are not in the same phenomenon, platform also provides a style different templates at the same time, teachers in the process of the construction of network course can be arbitrary choice, ensure the development efficiency of the course.

\subsection{The teaching mode of diversification.}

Teacher education teaching platform is the application subject of a bachelor degree in master of free normal education and remote education students, these two kinds of people to accept is the teacher education, but due to its training goal and talent level has great changes have taken place; there are inevitable differences in course learning mode [5]. Undergraduate course is given priority to with knowledge teaching, some necessary auxiliary learning activities; master of education study is composed of a lot of activities, assist to teach knowledge. Teacher education network teaching platform were considered in the design of the platform, the characteristics of the user selects the diversity of curriculum pattern, support knowledge teaching, research, inquiry learning, case study, the creation and management of the different pattern such as course, meet the needs of different groups of students.

\subsection{Social network teaching.}

The famous American social psychologist Stanley Mailgram in the 1960 s Mir graham first puts forward the theory of six degrees of segmentation: in the context of interpersonal, to make friends with any strange, and among the most as long as through six friends can achieve their goals. According to the theory of six degrees of separation, each individual's social circle have been enlarged, and finally become a large network [5].Later someone according to this theory, created the Internet service for social networks, social networking through acquaintances "acquaintance" development, formed the social networking services (SNS). Teachers' education network platform from six degrees of integral theory and social thoughts, constructing the virtual learning community, make learners build relationships in the teachers' education network platform, create a more authentic learning atmosphere, enhance the user's sense of belonging.

Teacher education network teaching platform for teachers' pre-service education and post-career training provides a personalized learning platform, platform to complete the teachers' teaching process records, including the growth of the planning of teachers, teaching behavior, teaching reflection and teaching achievements, form the electronic file cover, implements process evaluation for teachers' professional skills, at the same time also can form of teaching resources, to help novice teacher's professional development [4].

\subsection{The standardization of curriculum encapsulation.}

Teachers' education network teaching platform, a unified technical indicators, generate standardized course website, enable the programmed to barrier-free running on other teaching platform, such as Blackboard, Moddle and Saiky platform, etc.

In teachers' education network teaching platform, considering the teachers education also needs corresponding educational administration, therefore the platform must be implemented with the 
school, college teaching educational administration platform seamlessly, professional information, course information, teaching evaluation and so on teaching content and teachers' education teaching information communication [6]. Teachers' education network teaching platform design module is part of each module to reserve API interface, data communication between through apes interface to implement.

With the continuous development of information technology and society, more and more electronic products begin to apply in education field, based on mobile terminals mobile learning has become a hot topic of the academic discussion currently. In order to better support teachers in learning, the teacher education in the process of planning and construction of network teaching platform, considered more terminal support, in the device, smart phone terminal can access the platform, such as for online learning.

\section{The function of teachers' education network teaching platform design}

According to the requirement of the learning society to teacher education, and the characteristics of the users, the basic function of teachers' education network teaching platform module includes: curriculum management, online learning, resource management, activity management, answering questions, learning evaluation, eight user management and system management module, according to different permissions to users three classes of administrators, teachers and students, a total of 65 operations.

\subsection{Course management.}

Curriculum management refers to the system management personnel to teacher education courses in network teaching platform for the corresponding operation, its management includes two types of user administrators and teachers, the main operation including the creation of courses, the administrator audit resources, announcement, tracking the learning process, monitor the study situation, distribution network curriculum, the teacher's main operations include curriculum information, selecting course module, select template, set up the course [6].

\subsection{Online teaching.}

Teachers' education network teaching platform is to support the best feature of online teaching, online teaching module function design is scientific, whether complete determines the effect of teaching. Full display platform module online teaching is not only resources, but also integrating resources and services, self-study and collaboration, theory and practice, teaching and evaluation for the integration of three-dimensional teaching platform [6]. The module of user types is given priority to with teachers and students, the teacher's main operations include design course catalog, edit, learning content, set up the related resources, set up related activities, setting up learning process, students operation including autonomous learning and view the learning process.

\subsection{Resource management.}

Is the main component of network course resources, is one of the important auxiliary knowledge content [7]. In terms of teachers' education network teaching platform design resources, pay attention to the design of multiple forms of media resources, sensory experience for learners to provide intuitive, image, promote the learners' understanding of knowledge and master. Teacher education teaching platform of network resources management users are mainly teachers and students, the teacher's main operations include resource retrieval, resource upload, download, resource audit resources, resources classification, student's main operations include resources retrieval, resource, upload, download resources.

\subsection{Activity management.}

According to modern teaching theory, the knowledge is given priority to with activities in the network course. Learning activities help to arouse the enthusiasm of learners' learning, but also can reflect the subject status of the learners in online learning [7]. Therefore, teachers should improve the 
quality of network teaching, according to the different learning goals and content of knowledge, set up suitable learning activities, arrange specific learning tasks, clear the corresponding steps, supervise the learners to participate in activities, and provide feedback on implementation of activities. Teacher education network teaching platform of the manage users are mainly teachers and students, the teacher's main operations are free to discuss, self-study self-test, case analysis, online resources collection, explore and virtual experiment, practice, theme and the main operation have to participate in activities, students view the feedback information, etc.

\subsection{Answering questions of teaching.}

The interaction is an important part of network teaching platform, is also an important indicator to measure the quality of network teaching platform, enhance the communication between teachers and students [7]. Draw lessons from the current teacher education network teaching platform of answering model, the style of open-end mutual question answering system, such as Baidu knows, sine to ask, the user is made up of two categories, teachers and students, the teacher's main operations are synchronous answer, to respond to comments, common problems, the students' main operations are synchronized to ask questions, leave a message to the teacher, problem, the retrieval.

\subsection{Learning evaluation.}

Learning evaluation is an important form to measure the quality of network teaching, is generally one of the main functions of the network teaching. Teacher education network teaching platform of learning evaluation forms, main form of homework, papers and exams. Teachers in teaching platform layout, marking and statistics mainly for homework, group, organization of the entrance exam papers to the test, for homework scores, grades and test scores were statistically analyzed. Students mainly finish the homework; take exams, completed papers and query results.

\subsection{User management.}

Teacher education network teaching platform, including teachers, students, administrators, three different characters, each role in the process of application platform to realize the function is different. Therefore, needs to be developed for each part of the user a user center, so that they can easily manage their course, processing a variety of tasks. Students personal center including a list of the courses, pending tasks, toolbox, personal information management, learning management, learning group of management, etc.

\subsection{System management.}

System management is mainly to teacher education network teaching platform for the system configuration, safety management, data backup, user rights management, etc.

\section{Summary}

In this paper, according to the requirement of the education informatization of network course puts forward the design idea of teachers' education network teaching platform. Teacher education the main functions of the network teaching platform including course management, online learning, resource management, activity management, answering questions, learning evaluation, user management and system management, design and development of the current teachers' education network teaching platform has been basically completed, and set up many network course, the next step of work center of gravity is a research and development of teachers grow electronic bag concrete implementation plan, record the road of teacher's professional development, realize the teacher's professional development.

\section{References}

[1] Y. Mei, Introduction to the function of the college educational administration system analysis and design, Information science and technology, 2008, vol. 3, pp. 63-66. 
[2] Q.Y. Yang, The research and application of web technology in network teaching platform, Beijing: Beijing Jiaotong University, 2010, vol. 3, pp. 32-34.

[3] J. K. Zhu, Teaching based on web CMS web site management system, The design and implementation of electrochemical education research, 2009, vol. 6, pp. 82-84.

[4] M. Y. Li, Discuss the function of the college educational administration system and the design analysis, Information science and technology, 2012, vol. 5, pp. 36-38.

[5] X. B. Zhou, M. T. Li, GSM and WAP push technology in the school information management system, the application of a preliminary study, Journal of Zhejiang Industry University, 2008, vol. 4, pp. 491-494.

[6] P. T. Xu, WAP technology under the support of mobile learning research and exploration of the system, Development and application of computer, 2010, vol. 8, pp. 11-13.

[7] X. F. Zhang, Educational performance management system based on WAP2. 0, The design and implementation of computer, 2010, vol. 12, pp. 9-12. 